\title{
Local emergence and international developments of conservation trading systems: innovation dynamics and related problems
}

\author{
CARSTEN MANN* AND ARNO SIMONS \\ Innovation in Governance Research Group, Technische Universität (TU) Berlin, Secretariat FH9-1, \\ Fraunhoferstrasse 33-36, 10587 Berlin, Germany \\ Date submitted: 29 January 2014; Date accepted: 17 October 2014; First published online 5 \\ December 2014
}

\section{SUMMARY}

Conservation trading has developed as a policy instrument for biodiversity protection. This paper traces the emergence, development, and spread of conservation trading, focusing particularly on the formation and activities of an increasingly transnational policy instrument constituency, namely the actor group that has formed around the policy instrument in its support. The development of conservation trading was predominantly guided by a constituency of dominant business-oriented actors, beginning with mitigation measures in the USA and making later connections to international networks with a similar marketdriven orientation for environmental protection. By strategically combining agenda-driven research with the mobilization of political support, this constituency helped to establish conservation trading as a widely acknowledged policy solution applicable to various ecological and sociopolitical contexts. Yet, this was achieved, in part, at the cost of neglecting critical issues, such as the recognition of policy alternatives or socioecological or cultural context particularities. Whereas the development of conservation trading is sometimes portrayed as a rational process of neutral policy learning, this process, through its constituency, has developed a life and political momentum of its own, which must be acknowledged when engaging with the design and implementation of better conservation policies. A forward-looking social policy assessment approach is required, which opens up policy design discourses for debate and reflexive engagement. Acknowledging possible shortcomings with a broad range of concerned societal actors can help to assure policy transparency, add specificity, and increase the sound ecological and societal embedding of conservation trading.

\footnotetext{
*Correspondence: Dr Carsten Mann Tel: +49 3031428872
} Fax: +493031426917 e-mail: carsten.mann@tu-berlin.de
Keypords: constituency, innovation dynamics, policy instrument, social policy assessment

\section{INTRODUCTION}

In response to increasing land-use pressures and continuous loss of biodiversity, biodiversity offsets have been developed as a new policy solution for regulating the compensation for impacts on biological diversity (ten Kate et al. 2004). While impacts and offsets are intended to be functionally and spatially equivalent, possibilities to disconnect, aggregate and trade with offsets, using pooling and banking models, have grown in importance in policy practice. Governments around the world consider, plan, or have already implemented conservation trading schemes, also known as mitigation, species, habitat or biodiversity banking and trading, as a means to address the problem of biodiversity loss. At their core, conservation trading schemes allow for the compensation of impacts in one place with conservation or restoration measures in other places, if stricter mitigation measures, such as avoidance or reduction, are not feasible (ten Kate $e t$ al. 2004). Compensation can happen on a case-by-case basis, by offsetting the impacts of specific development projects through additional protection measures at a different site (Wheeler \& Strock 1995). Alternatively, compensation may take the form of standardized banking procedures, of issuing generic biodiversity credits for protection measures, which can be produced in advance and independently of concrete impacts, and later used to compensate biodiversity losses created by other projects (Fox \& Nino-Murcia 2005; Mead 2008). This latter form can be linked to regulations that provide for private conservation banks, which generate and offer credits on a commercial basis (Bauer et al. 2004).

The creation of conservation trading schemes is regarded as an innovative form of governance for biodiversity protection, which may complete or even substitute for direct interventions by the state (Haddad 1997; Jordan et al. 2003, 2005; TEEB [The Economics and Ecosystems and Biodiversity Initiative] 2008; Tommel \& Verdun 2008). Such schemes may reduce regulatory costs, dampen the adversarial nature of regulation and support economic growth, while still achieving regulatory and conservation goals (Mead 2008). In contrast to such high expectations, empirical assessments 
of existing conservation markets have produced mixed results (Wilcove \& Lee 2004; Fox \& Nino-Murcia 2005), and critics have warned that conservation trading, along with the resulting commodification of nature, tends to endanger environmental protection rather than promoting it (see for example Robertson 2004, 2006; Sullivan 2012). A problem in assessing the performance of conservation trading schemes seems to be a lack of data on trade volumes and environmental effectiveness (Wilcove \& Lee 2004; Madsen et al. 2011). Beyond this problem, the question whether or not conservation trading is effective or preferable also depends on the ideological and epistemic standpoint. Empirical political science research on policy instrumentation has shown that policy instruments are bearers of values rather than neutral tools; their design and choice are often a matter of fierce ideological conflict (Peters \& Van Nispen 1998; Eliadis et al. 2005; Lascoumes \& LeGales 2007; Voß and Simons 2014).

Given the controversial status of conservation trading, the success of this instrument in terms of international diffusion is puzzling. Thus, from a political science perspective on conservation trading systems, a series of questions become relevant, which have so far been neglected in the conservation policy discourse and which we aim to address in this paper. While a major focus has been on the design, implementation and performance of conservation trading, there is a research gap concerning the promotion of this instrument in academia, the private sector and politics (Wolff et al. 2015).

We aim to shed more light on the innovation process of conservation trading systems and to answer the following questions: Why and how has conservation trading acquired its current status as a promising policy instrument despite concerns about its ecological effectiveness? Who promotes conservation trading, for which aims, and by which means? What connects the design and implementation processes of conservation trading schemes in different countries and what are the effects of such connections? Our strategy in supporting the search for and innovation of better conservation policies is thus not to study the effectiveness or cost-efficiency of conservation trading narrowly but add to the discourse on the political dynamics that lead to the diffusion of this instrument and its perception as a promising new policy solution.

We review the theoretical literature on policy instruments and policy ideas, introduce the notion of a policy instrument constituency as a network of actors that forms around the support of a new or given policy solution, and outline our methodological approach. We applied this approach to a case study on the emergence and growth of the conservation trading constituency and their influence on the development of conservation trading as a new policy instrument. The case of conservation trading seems particularly suitable for studying policy innovation processes, as it demonstrates the vast and ongoing development of a policy instrument that became recognised in the international conservation policy discourse. Starting from early ideas to compensate for impacts on wetlands, which emerged in the practice of handling mitigation requirements in the USA, we describe the 'innovation journey' (Van de Ven et al. 1999) of conservation trading, namely its development history via institutionalization processes on the regional and federal level until its establishment as a recognized policy solution on a global level. A particular focus will be on the involved actors and their activities leading towards the recognition of trading systems for biodiversity conservation on regional, national, and international policy agendas, as well as on the ongoing negotiation processes concerning the design and application of conservation trading schemes. Our aim was to highlight the social dynamics of policy innovation processes, captured in the notion of instrument constituencies, as well as the associated problems, and to identify trends toward the commodification of nature and 'expertization' (where only experts are deemed suitable to assess policy) of environmental policymaking.

\section{THEORY AND METHODS}

Our theoretical orientation is based on the assumption that differing and in parts conflicting visions exist about how to deal with policy problems, here in the loss of biodiversity. While the political process often becomes conceptualized as a matter of rational problem solving, where policy instruments are chosen from an available pool of instruments on the basis of their efficiency and effectiveness, we reviewed three strands of political sciences literature that complemented each other in producing an alternative view on policy change and instruments.

The first strand consists of policy change theories that highlight the role of policy ideas in the policy process; so-called ideational approaches. According to the advocacy coalition framework (ACF) of Sabatier and Jenkins-Smith (1993), policy change is explained as the struggle between advocacy coalitions. Since advocacy coalitions differ with regards to their belief systems, they have different perceptions of the political situation and thus pursue different goals and strategies. Consequently, the choice of policy instruments is explained as following directly from the beliefs of policymakers, who choose them as means to realize their objectives, given their belief systems (Braun \& Capano 2010). Hall's (1993) policy paradigm approach is another prominent ideational approach and similar to the ACF. Policy paradigms are in essence what are called belief systems in the ACF. They serve to specify policy problems and goals. Hall (1993) argued that policy instruments were much easier to change, on the basis of social learning, than other aspects of policy paradigms. In fact, the change of policy instruments according to changing perceptions amounts to 'normal policy making', namely a process that adjusts policy without challenging the overall terms of a given policy paradigm (Hall 1993, p. 279). A third approach is that of discourse coalitions (Hajer 1993; Bulkeley 2000), a concept rooted in the assumption that policymaking is not only a struggle of ideas and diverging meanings, but first of all a process of making meaning. In this view, policy beliefs do not fall from the sky nor are they determined by exogenous interests, as both the ACF and Hall's paradigm 
approach might suggest, but they are constantly renegotiated in social practices, which give meaning to physical and social realities. Policy instruments are then supported or opposed on the basis of the meaning they have for different actors. Discourse coalitions are groups of actors that form around shared concepts and story lines and try to impose their view of the reality on others (Hajer 1993). Discourse coalitions are much more transient than advocacy coalitions or paradigm schools. Their members do not necessarily need to share deep core beliefs and they may jump from one discourse coalition to another more easily. Discourse and discourse coalitions are thus more open concepts (Braun \& Capano 2010).

Whereas ideational theories of policy change tend to treat policy instrumentation as a side issue, and are in this regard insufficient to explain the making of policy instruments, a second relevant strand of literature specifically focuses on policy instruments (Linder \& Peters 1998; Hood 2007; Lascoumes \& LeGales 2007; Voß 2007; Voß \& Simons 2014). In this policy instrument literature there is a general, if often implicit, agreement that instrument choice is a deeply political process (Peters \& Van Nispen 1998; Salamon 2002; Eliadis et al. 2005; Lascoumes \& LeGales 2007). It is assumed, for example, that actors often negotiate policy strategies and instruments as a matter of collective interests, positions, and preferences. Going one step further, newer approaches see policy instruments as social institutions capable of structuring policy-making according to their own logic (Lascoumes \& LeGales 2007; Wolff et al. 2015). It has also been reasoned that, just as instruments can follow ideas, ideas can also follow instruments (Schneider \& Sidney 2009: Braun \& Capano 2010). This is because instruments as social institutions bear values, influenced by a specific interpretation of the social and of the mode of regulation involved (Lascoumes \& LeGales 2007, p. 4).

A number of authors have further emphasized that the diffusion of policy instruments cannot be explained through political demand alone; the active promotion of instruments by specific actor groups must also be acknowledged (Stone 2004; Voß 2007; Peck \& Theodore 2010; Voß \& Simons 2014; Simons \& Voß 2015). This is to say that the development and spread of policy instruments is driven both by demand and supply side dynamics (Voß 2007; Voß \& Simons 2014). To give an example, the development and spread of emissions trading has coincided and was effected by the growth of an emissions trading constituency, namely an actor group that formed around the policy instrument, rather than a particular policy problem (Voß \& Simons 2014; Simons \& Voß 2015). Through their constituencies, policy instruments gain political momentum, because they are advocated from within. Constituencies develop a reflexive interest in retaining and expanding 'their' instrument and therefore engage in advocacy activities.

Instrument constituencies do this by engaging in the discursive construction (Keller 2011) of policy instruments and the problems these instruments address. This process also includes the institutionalization of this discourse, such as its inscription into actual law. Part of the work of instrument constituencies may consist in standardizing the design of policy instruments to enable their wider application (Simons et al. 2014). The general appeal of such generic policy models remains the expectation of comparable results (Peck \& Theodore 2010). However, this one-size-fits-all mentality behind policy innovation models seems especially inappropriate in the case of conservation policy, where blueprint approaches often fail to sufficiently embrace the diversity of local settings and the complexity of ecosystems, leading to unanticipated side-effects that may result in poor natural resources management and environmental degradation (Ostrom 2007, 2011; Galaz et al. 2008; Hagedorn 2008; Mann \& Absher 2014).

We analysed two types of data. First, we examined the existing (secondary) literature on the emergence and development of conservation trading systems, including literature on broader political trends, the policy instruments involved in species conservation and impact mitigation, as well as on related problems and issues. Second, we analysed (primary) documents produced during the political processes of creating conservation trading systems, such as statutes, agency or think tank reports, position papers, protocols, and scientific evaluations of instrument performance, with the goal of identifying the emergence and strategic use of arguments for or against the use of certain instrument designs in a particular context. We further incorporated a series of problem-centred expert interviews with actors involved in advocating, criticizing, or setting up and operating conservation trading systems. The results of these interviews were published previously (Simons 2013a, $b$; Mann \& Absher 2014).

\section{RESULTS}

The first ideas for conservation trading systems emerged in the USA as an alternative mechanism to traditional regulatory approaches for biodiversity protection and the use of natural resources. In the mid-1970s, environmental policy mainly consisted of command-and-control regulations, especially for water, air, and species protection, regulated under the Clean Water Act (CWA), the Clean Air Act (CAA), and the Endangered Species Act (ESA), respectively (Klyza \& Sousa 2010). In response to a political mood shift away from environmental concerns and toward economic and energy security, the USA's policy changed from strict environmental regulations towards more flexible approaches (Meidinger 1985; Dryzek et al. 2002). In this context, the USA's Environmental Protection Agency (EPA) started experimenting with flexible regulations and mitigation mechanisms. A mitigation hierarchy was developed as a hierarchical sequence of steps for assessing development projects, ranging from impact avoidance and minimization, to the possibility of offsetting losses directly as the last option (Hough \& Robertson 2009). 
In practice, however, such mitigation activities, which were mostly carried out as uncoordinated, small and spatially disconnected case-by-case compensation, proved difficult. As an innovative alternative inspired by the EPA's experiences with emission trading, the possibility to 'bank' either wetlands (referred to as wetland banking) or species habitat (referred to as conservation banking) for future use were introduced as concepts where public-private partnerships appeared to offer better flexibility in site selection and facilitate conservation objectives. Banking is a particular case of mitigation action, introducing a trading element for offset actions. From an agency perspective, banking was seen as an opportunity to add private land to the federal reserve system by enrolling private actors (Soileau et al. 1984).

\section{Institutionalization and emergence of a national supporters' base for conservation trading}

In its original form, a mitigation bank is a parcel of privately or publicly owned land that serves as a stock of wetland and/or species habitat to offset habitat impacts elsewhere. In exchange for managing land for species and habitat conservation or restoration, the bank owner is granted 'credits' by the responsible wildlife agency. These credits can then be traded to parties who need to satisfy legal mitigation/compensation requirements (Fox \& Nino-Murcia 2005; Mead 2008). Mitigation banking thus essentially operates as a free-market enterprise allowing for the sale, purchase or trade of species habitat, as represented by species credits. Once all of a bank's credits are sold, the land is managed as a preserve in perpetuity, and financed by an endowment fund (US FWS [Fish and Wildlife Service] 2009).

The first mitigation banks in the early 1980s under the supervision of the US FWS were mainly established ad hoc as non-commercial ventures of state agencies to satisfy their own project compensation needs (Carroll et al. 2008; Hough \& Robertson 2009). At that time, commercial trading was still an exception. The development towards third party provision of banks began in the early 1990s (Hough \& Robertson 2009). This development was fostered by a series of reports resulting from national wetland mitigation banking studies initiated by the Corps Institute for Water Resources (Hough \& Robertson 2009). In these reports, it was argued that an expansion of wetland banking to a wider set of actors would yield ecological and economic benefits.

Starting in 1995, federal and state mitigation banking guidance and legislation were put in place to support commercial wetland banking (Federal Guidance 1995). The new regulations, although directed at wetland banking, also gave state agencies, local governments, and the private sector the procedural and conceptual guidance for conservation banking under the legal requirements of the ESA of 1973. As a result, a specialized conservation trading 'industry', essentially a private credit market, started to develop, bundling and combining expertise in environmental restoration, finance, law, real estate, construction, and local market conditions.
In 1995, the California Resource Agency and the California Environmental Protection Agency jointly released the 'Official Policy on Conservation Banks' (Wheeler \& Strock 1995). The same year, the first conservation bank, 'Carlsbad Highlands,' was created after the model of wetland mitigation banks. In 1996, the FWS issued the first formal ESA consultation, promoting the use of conservation banks. Other sectors like transportation followed to include banking as a mitigation option in their policies and procedures, as outlined in the ESA.

However, even though official policy guidance was in place, the implementation practice of mitigation banking differed widely, as federal and state natural resource agencies observed (see Fox \& Nino-Murcia 2005; Mann \& Absher 2014). Only a few banks were strictly modelled after the policies, with most banks being established under individual agreements between agencies and bank sponsors, with very little exchange of information or coordination (ten Kate et al. 2004). Actors involved in mitigation banking had very different interests, some of which stood in the way of achieving the policy's goal of protecting endangered species and their habitats (Mann \& Absher 2014). Whereas the agencies were concerned about the sound institutional embedding of conservation banking into larger structures of conservation networks, as well as about directing banks to ecologically valuable sites, business-oriented actors selected bank sites for criteria of profit maximization. Such different rationales for bank establishment were leading to manifold trade-offs in bank establishment and permitting processes. Attempting to streamline banking processes, the US FWS (2003) defines mitigation requirements under the ESA, institutionalizing conservation banking at the federal level in the USA.

After the institutionalization and official promotion of banking as a (last) mitigation option, commercial banking took off. According to an Environmental Law Institute (ELI 2002) report, entrepreneurial mitigation banking became a mainstream option for the loss of wetlands as well as for habitat of endangered species after its institutionalization. Such policy initiatives played an important role for the dissemination of the idea of conservation credit trading, but not alone. The USA has created an environment where entrepreneurs can create and sell environmental services for profit.

\section{The formation of an international conservation trading constituency}

The institutionalization processes were closely linked to the formation of a strong national supporter base. Debates about incentive measures for biodiversity conservation created an atmosphere of excitement in the business sector. While many industry and business actors felt threatened by the prospect of new regulations (Dunn 2002), others saw new business opportunities. Analysts were predicting at the time that carbon credits and allowances might become one of the world's 
most valuable commodities, and there was a similar hope that much could be earned with some sort of biodiversity trading (Carroll et al. 2008; ten Kate et al. 2004; Madsen et al. 2010).

It soon became clear that the promotion of conservation trading required the bundling of information and the exchange of scattered experiences with wetland and conservation banking approaches. As a response, in 1988, the EPA initiated a new annual National Mitigation and Conservation Banking Conference with the goal to foster exchange among involved actors and organize scientific input. The same year, the National Mitigation Banking Association (NMBA) was founded to support and improve mitigation banking legislation. It represents bankers and service providers, engages in lobbying activities, and organizes conferences and training courses for its members.

On the international level, support for ecosystem service commodification increased during the 1990s (Robertson 2004). Between 1996 and 1998, representatives from the forestry industry, environmental groups, finance, and community conservation set up a USA think tank named Forest Trends (FT), which became a leading advocate of conservation trading and other environmental markets, functioning as a matchmaker for bringing together diverse experts with potential financiers (Daily \& Ellison 2003). Such efforts by FT and others led to the formation of a strong, transnational and explicitly business-oriented constituency for biodiversity trading.

In 2001, a group of oil and gas companies teamed up with environmental groups and think tanks including Fauna and Flora International, the International Union for Conservation of Nature (IUCN), and The Nature Conservancy (TNC) to form the Energy and Biodiversity Initiative, which stated that voluntary or required biodiversity offsets 'should be the minimum expected standard by which all companies operate' (The Energy \& Biodiversity Initiative 2003, p. 47). Others highlighted the 'business case' of potential credit banking (Eftec et al. 2010) or biodiversity offsets (ten Kate et al. 2004) and communicated these ideas, among other things, to the Katoomba Group, the IUCN's Global Biodiversity Forum, and the Convention on Biological Diversity (CBD; see Insight Investment 2004).

In 2004, the Business and Biodiversity Offsets Programme (BBOP) emerged as another key driver of transnational dealing with biodiversity trading. It was set up by FT and Conservation International, and quickly enrolled over 50 companies, financial institutions, governments and civil society organizations focusing on the question of compensation for impacts on biological diversity. BBOP produces guidance for the design of biodiversity offsets (Crowe \& ten Kate 2010), supports pilot projects and disseminates best practice models (BBOP 2004) around the world, and has become a widely recognized venue of international exchange (Darbi et al. 2009). As such, specialized networks like FT, ELI and BBOP function as policy entrepreneurs. They are subsuming diverse actors and interests, thus bundling efforts for pushing 'their' policy solution on the international political agenda.

\section{International agenda setting}

Today, conservation trading schemes are developed and discussed in many places around the world. Such efforts are actively promoted and coordinated by a growing transnational instrument constituency, seeking to streamline the development of such schemes by organizing the exchange of practical experience and by promoting dialogue between policymakers, industry and the conservation community (ten Kate et al. 2004). Constituency actors coordinate information and work on the establishment of best practice standards. Conservation trading became the common umbrella label for existing and planned banking and credit-trading schemes, which were now predominantly discussed as specific applications of the economic theory of tradable permits (see ten Kate et al. 2004; Carroll et al. 2008; Madsen et al. 2010; Simons et al. 2014).

In recent years, BBOP linked up with Ecosystem Marketplace (EM), FT's online platform for constituency exchange and information on carbon, water, and biodiversity markets. As such the discourse on conservation trading also became influenced by the development of emission trading under the Kyoto Protocol. The rationale of launching EM was to stimulate market creation for environmental policy through information services that help a clear understanding of the policy changes that drive these markets, as well as the science that underpins them (Ecosystem Marketplace 2010).

As an outcome of the activities of these policy entrepreneurs, market-based instruments (MBI) are high on the agenda of many policy initiatives at the national and also at the international level. The Millennium Ecosystem Assessment identified a greater use of MBIs for the protection of biodiversity and ecosystem services as a promising way forward (Millennium Ecosystem Assessment 2005, p. 21). Within the CBD, a dedicated work programme started exploring various MBIs for use in the context of biodiversity protection (COP 10 2010). The Organisation for Economic Cooperation and Development (OECD) launched a Working Group on the Economic Aspects of Biodiversity (WGEAB, now known as the Working Party on Biodiversity, Water and Ecosystems, WPBWE), leading to various events, reports and handbooks on market creation and finance mechanisms for biodiversity conservation (OECD 1999, 2013). Major support for international conservation trading also came from the The Economics and Ecosystems and Biodiversity (TEEB) Initiative (TEEB 2008, 2010). And, during the Rio +20 United Nations Conference on Sustainable Development (USCSD) the Green Economy discourse was prominently addressed (UNCSD 2012). These developments have been creating great expectations for a new specialized conservation trading industry, which views conservation trading as a profitable business case. 
Conservation trading is increasingly embraced as a potentially universal solution to nature conservation that needs to be further refined and tested under different context conditions. Recently, EM identified 45 existing compensatory mitigation programmes around the world, the USA's wetland and species banking being the widest in scope (Madsen et al. 2011). Together, the world's biodiversity markets are estimated to have a total value of at least US\$2.4-4.0 billion with $\geq 187000$ ha of land protected under the various programmes (Madsen et al. 2011). To a great extent, this is the achievement of the conservation trading constituency such as FT, EM, ELI, BBOP and others who have influenced agenda-setting processes on various levels of policymaking and introduced relevant policy communities to concepts pertinent to biodiversity conservation.

\section{DISCUSSION}

We described the growth of a policy instrument constituency as the main driver of innovation of conservation trading systems. What had started in the USA in the realm of wetland and species protection policy, developed toward a promising globally-recognized instrument for biodiversity conservation. Its growing application at the international level has been carried by a transnational network of dedicated experts that coordinates information, makes connections between like-minded discourses on environmental markets, and largely manages the science-policy-industry interfaces. The conservation trading constituency consists of heterogeneous actors of different fields of expertise. Their engagement is connected to particular and different interests in developing and expanding conservation trading design and implementation. For example, agencies see banking mainly as a means to enlarge and better connect protected areas systems, scientists deal with questions of defining the equivalence of loss and compensation, and business actors have an interest in establishing biodiversity markets and service infrastructures. Together, all these actors have contributed to the development and expansion of conservation trading systems on a global scale. While constituency formation and specialization on particular policy solutions in itself is not a bad thing (after all this is a network of actors pushing for policy innovation), we see two related problems with this dynamic.

First, there is a marketization trend in the discourse on species and habitat protection, pushed by dominant constituency actors who advocate a market-based version of compensatory mitigation and offsets, such as commercial banking. Pro-market governmental and non-governmental organizations, coalitions and initiatives, such as the OECD, the CBD, Forest Trends, IUCN, BBOP, or TEEB, deliberately push for a shift in biodiversity protection toward marketization of biodiversity credits. Such efforts are backed up by a growing private conservation trading industry, which is especially well developed in the USA context. The problem with this marketization trend is that alternative policy approaches, such as command-and-control regulations, land purchase, protection contracts, or non-commercial forms of banking, which may equally be able to tackle the problem of biodiversity loss, become relegated to the background simply because they do not have constituencies with similar lobbying powers behind them. A market-based approach to biodiversity protection promises business opportunities, such as providing particular services and infrastructures, which attract powerful corporate interests that may eventually outweigh noncorporate interests in the protection of biodiversity. One result was, for instance, that the established market structures seemed to be insufficient for directing bank location to the most ecologically valuable sites with only limited control of the regulatory agencies (Mann \& Absher 2014).

Closely linked to the marketization trend, we further sense an 'expertization trend' (see Yearley 1994 and Eden 1998 on the empirical phenomenon of expertization). The policy design discourse on conservation trading to a large degree remains an expert discourse, taking place among constituency actors and thereby being largely shielded off from public debate. This can be problematic because decisions made in expert circles also affect non-expert audiences, for example private and public actors in implementation contexts. At the same time, the expert discourse on conservation trading design tends to push for a one-size-fits-all approach to compensatory mitigation (such as standardized banking procedures; see BBOP 2012), which runs the risk of neglecting context specific specificities. The danger here is that the process of designing and developing conservation trading becomes too decoupled from the local ecological and social dynamics at the sites of intended policy implementation and may fail to reach intended policy objectives (Mann \& Absher 2014). Both these trends have to do with the fact that through its constituency, conservation trading has developed a social life of its own. Whereas policy choice is often understood as a process where policymakers choose the most appropriate and effective tool from a pool of equally available tools, our analysis shows that all tools are not equal: some have a stronger constituency behind them than others, thus exerting a stronger influence on the process of policy choice. To the extent that instrument constituencies lobby for particular instrument designs and persuade policy communities to implement these designs, they become political actors in their own right without necessarily being transparent about their underlying values and interests.

As such, the specialization, expertization and influence of instrument constituencies in policy design processes is not inherently bad or inefficient, but seems also necessary for dealing with particular socioecological interactions and problems. However, we wish to stress that the current promotion of an instrument should not be taken as an indicator for the instrument's actual efficiency or effectiveness, but as a test of responsiveness to unresolved issues for future nature-conservation policy. There still are serious challenges to implementing conservation trading schemes that need to be addressed. For example, the issue of complex and diverse ecological conditions versus simple measurement units of functional or spatial equivalence for trade, the reduction of 
biodiversity and ecosystems values to monetary terms, or their general suitability for dealing with the loss of biodiversity (Robertson 2006; Mann et al. 2014). Many of these issues contain as much a functional as a political dimension, as became obvious in a workshop on future challenges in the design and use of biodiversity offset schemes (Mann et al. 2014). Decisions for or against certain policy forms and designs are often linked to fundamental and potentially antagonistic philosophies and rationalities of how to see, use and value nature (Mann et al. 2014). One key challenge for the future of biodiversity policies is to make such decisions more explicit in order to allow the concerned public to judge and engage with such policies.

Meeting ambitious policy targets for biodiversity protection, as they are set in the CBD and the European Union, requires a critical review of existing and emerging policy instruments to learn from past experiences and to improve their design (Paloniemi et al. 2012). This suggests that an approach is needed that opens up policy design discourses for a larger set of concerned actors to increase reflexive debates and learning for policy development. Such participatory innovation approaches have long been discussed in the area of technology assessment (Rip et al. 1995; Schot \& Rip 1997; Rip \& te Kulve 2008; Robinson 2009). Here, the idea is to open the process of technological design for consideration of broader societal concerns, in direct interaction with affected societal groups. Technologies shall be shaped in the process of their making, so that, from the outset, they are responding and adapted to the contexts in which they are expected to be used. Practically, for conservation trading systems, this comes down to an involvement of actors from beyond the instrument constituency networks, who are directly concerned with the development of conservation trading, as well as actors who voice a critical perspective on the policy project (Garud \& Ahlstrom 1997). Such actors can be private landowners, environmental non-governmental organizations, critics of market-based approaches for nature and biodiversity protection, and/or proponents of alternative policy solutions that are able to reintroduce alternative perspectives and relegate critical issues in the design discourse.

Ideally organized as a continuous process, open fora, which bring all these actors together, would discuss a range of future projections of policy instrument developments and potential impacts. These fora would serve as bridging events and would aim to create awareness of potential opportunities and challenges at different stages of policy development, stimulating coordination and responsiveness between policymakers and policy-takers. Instead of waiting for generic policy designs to enter society, such social policy assessments should also be implemented on a transnational level (Mann \& Voß 2015).

\section{CONCLUSIONS}

While issues such as biodiversity loss and sustainable development provide an important reference for policy justification, they do not fully explain the emergence and development of conservation trading systems. As we have shown in this analysis, the development of conservation trading as a globally circulating policy blueprint has been closely related to the growth of an instrument constituency strategically promoting their preferred instruments in international policy discourses. In their joint engagement, actors mutually enrolled each other for the realization of particular versions and expectations of conservation trading. The constituency has developed capacities for strategic collective action in pursuing these interests and thereby turned into a political actor in its own right.

However, surprisingly little attention has so far been paid to the influence of instrument constituencies on the policy process and thus the political dimension of policy instrument design and choice (Voß \& Simons 2014; Simons \& Voß 2015). Where instrument constituencies operate transnationally and promote the standardization of policy designs, lessening the significance of crucial design issues and policy alternatives can cause socioecological and cultural problems after policy implementation on a large scale. There is a high risk that diversity and contextual differences are ignored and thus fail to work (see Mann \& Absher 2014). Policymakers and policy analysts alike should therefore begin to take this constituency seriously as an influential political actor with a strong interest in sustaining and further expanding conservation trading.

As the design and use of conservation trading systems begins to stabilize, it is crucial to keep asking questions as to the effectiveness and legitimacy of pursued innovations and how they are shaped. For practical policy and decision-making implications, we suggest opening up the policy design process to include actors from outside the boundaries of instrument constituencies. Debating challenging futures of policy designs, reflecting and learning from past implementation experiences, and acknowledging possible shortcomings with a broad range of concerned societal perspectives can help to inform policymaking and lead to more robust, or societally-embedded policy solutions.

\section{References}

Bauer, M., Fox, J. \& Bean, M.J. (2004) Landowners bank on conservation: the US Fish and Wildlife Service's guidance on conservation banking. Environmental Law Reporter 34(8): 1071722.

BBOP (2004) Who we are: about BBOP [www document]. URL http://bbop.forest-trends.org/pages/about_bbop

BBOP (2012) Biodiversity offset design handbook [www document] URL http://www.forest-trends.org/documents/ files/doc_3101.pdf

Braun, D. \& Capano, G. (2010) The missing link: policy ideas and policy instruments. Introductory Paper to the ECPR Joint Session Workshop on Policy Ideas and Policy Instruments, March 23-27, Münster, Germany [www document]. URL http://ecpr.eu/Filestore/PaperProposal/a4357e25-a9b2-445589f1-0d6c2ff9f2e2.pdf 
Bulkeley, H. (2000) Discourse coalitions and the Australian Climate Change Policy Network. Environment and Planning C: Government and Policy 18(6): 727-48.

Carroll, N., Fox, J. \& Bayon, R. (2008) Conservation and Biodiversity Banking: A Guide to Setting Up and Running Biodiversity Credit Trading Systems. London, UK: EarthScan.

COP 10 (2010) Report to the Tenth Meeting of the Conference of the Parties to the Convention on Biological Diversity. UNEP/CBD/COP/10/27, 20 January 2011 [www document]. URL http://www.cbd.int/doc/meetings/cop/ cop-10/official/cop-10-27-en.pdf

Crowe, M. \& ten Kate, K. (2010) Biodiversity offsets: policy options for government. Draft report [www document]. URL http://www.forest-trends.org/publication_details.php? publicationID $=3079$

Daily, G. \& Ellison, K. (2003) The Nem Economy of Nature: The Quest To Make Conservation Profitable. Washington, DC, USA: Island Press.

Darbi, M., Ohlenburg, H., Herberg, A., Wende, W., Skambracks, D. \& Herbert, M. (2009) International approaches to compensation for impacts on biological diversity. Final report [www document]. URL http://www.forest-trends.org/ documents/files/doc_522.pdf

Dryzek, J. S., Hunold, C., Schlosberg, D., Downes, D. \& Hernes, K.-H. (2002) Environmental transformation of the state: the USA, Norway, Germany and the UK. Political Studies 50(4): 65982.

Dunn, S. (2002) Down to business on climate change: an overview of corporate strategies. Greener Management International 39(15): $27-41$.

Ecosystem Marketplace (2010) Overview: about the Ecosystem Marketplace [www document]. URL http://www. ecosystemmarketplace.com/pages/dynamic/web.page.php? section $=$ about_us\&page_name $=$ overview

Eden, S. (1998) Environmental issues: knowledge, uncertainty and the environment. Progress in Human Geography 22(3): 42532.

Eftec, IEEP, ten Kate, K., Treweek, J. \& Ekstrom, J. (2010) The use of market-based instruments for biodiversity protection: the case of habitat banking. Appendix case studies [www document]. URL http://www.forest-trends.org/documents/files/doc_2410.pdf

ELI (2002) Banks and fees: the status of off-site wetland mitigation in the United States [www document]. URL http://www.eli.org/wetlands-compensatory-mitigation/ banks-and-fees-study

Eliadis, F. P., Hill, M. M. \& Howlett, M. (2005) Designing Government. From Instruments or Governance. Montreal, Canada: McGill-Queen's Press.

Federal Guidance (1995) Federal guidance for the establishment, use and operation of mitigation banks. Federal Register 60(43): 12286 [www document]. URL http://www.gpo.gov/ fdsys/granule/FR-1995-03-06/95-5280

Fox, J. \& Nino-Murcia, A. (2005) Status of species conservation banking in the United States. Conservation Biology 19(4): 9961007.

Galaz, V., Olsson, P., Hahn, T., Folke, C. \& Svedin, U. (2008) The problem of fit among biophysical systems, environmental and resource regimes, and broader governance systems: insights and emerging challenges. In: Institutions and Environmental Change, ed. O.R. Young, L.A. King \& H. Schroeder, pp. 147-186. Cambridge, MA, USA: MIT Press.
Garud, R. \& Ahlstrom, D. (1997) Technology assessment: a sociocognitive perspective. Fournal of Engineering and Technology Management 14(1): 25-48.

Haddad, B. M. (1997) Putting markets to work: the design and use of marketable permits and obligations. OECD Publishing [www document]. URL http://www.oecd.org/ gov/regulatory-policy/1910849.pdf

Hagedorn, K. (2008) Particular requirements for institutional analysis in nature-related sectors. European Reviem of Agricultural Economics 35: 357-384.

Hajer, M. A. (1993) Discourse coalitions and the institutionalization of practice: the case of acid rain in Britain. In: The Argumentative Turn in Policy Analysis and Planning, ed. F. Fischer \& J. Forester, pp. 43-76. Durham, NC, USA: Duke University Press.

Hall, P. A. (1993) Policy paradigms, social learning, and the state: the case of economic policymaking in Britain. Comparative Politics 25(3): 275-96.

Hood, C. (2007) Intellectual obsolescence and intellectual makeovers: reflections on the tools of government after two decades. Governance 20(1): 127-44.

Hough, P. \& Robertson, M. (2009) Mitigation under section 404 of the Clean Water Act: where it comes from, what it means. Wetlands Ecology and Management 17(1): 15-33.

Insight Investment (2004) Investor responsibility bulletin company engagement and voting reports. April to June 2004 [www document]. URL http://www.sgcc.com.cn/csr/ gwqy/images/20071227/7234.pdf

Jordan, A., Wurzel, R. K. W. \& Zito, A. (2003) New Instruments of Environmental Governance? National Experiences and Prospects. New York, NY, USA: Routledge.

Jordan, A., Wurzel, R. K. W. \& Zito, A. (2005) The rise of 'new' policy instruments in comparative perspective: has governance eclipsed government? Political Studies 53(3): 477-96.

Keller, R. (2011) The sociology of knowledge approach to discourse (SKAD). Human Studies 34: 43-65.

Klyza, C. G. \& Sousa, D. (2010) Beyond gridlock: green drift in American environmental policymaking. Political Science Quarterly 125(3): 443-463.

Lascoumes, P. \& LeGales, P. (2007) Introduction: understanding public policy through its instruments? From the nature of instruments to the sociology of public policy instrumentation. Governance 20: 1-21.

Linder, S. H., \& Peters, B. G. (1998) The study of policy instruments: four schools of thought. In: Public Policy Instruments: Evaluating the Tools of Public Administration, ed. P. B. Guy \& F. K. M. van Nispen. Cheltenham, UK: Edward Elgar.

Madsen, B., Carroll, N. \& Moore, B. (2010) State of biodiversity markets report: offset and compensation programs worldwide [www document]. URL http://www. ecosystemmarketplace.com/documents/acrobat/sbdmr.pdf

Madsen, B., Carroll, N., Kandy, D. \& Bennet, G. (2011) 2011 update: state of biodiversity markets. Ecosystem Marketplace [www document]. URL http://www.ecosystemmarketplace.com/ reports/2011_update_sbdm

Mann, C. \& Absher, J. D. (2014) Strategies for adjusting policies to institutional, cultural and biophysical context conditions: the case of conservation banking in California. Fournal of Land Use Policy 36: $73-82$.

Mann, C. \& Voß, J.-P. (2015) Articulating future scenarios of policy instrument development: enhancing sustainable innovation in governance by opening design processes for debate. In: 
Transdiciplinarity for Sustainability. Demand and Challenge, Routledge Series: Studies in Environment, Culture and Society, ed. M. Padmanabhan (in press). New York, NY, USA: Routledge.

Mann, C., Voß, J.-P., Simons, A., Amelung, N. \& Runge, T. (2014) Challenging futures of biodiversity offsets and banking. Critical issues for robust forms of biodiversity conservation. A report based on an interactive, anticipatory assessment of the dynamics of governance instruments, 19 April 2013. Technische Universität (TU) Berlin, Berlin, Germany [www document]. URL http://www.innovation-in-governance.org/fileadmin/user_ upload/Publications/Biodiversity_offsets_banking_challenging futures_report_final.pdf

Mead, D. L. (2008) History and theory: the origin and evolution of conservation banking. In: Conservation and Biodiversity Banking. A Guide to Setting Up and Running Biodiversity Credit Trading Systems, ed. N. Carroll, J. Fox \& R. Bayon, pp. 9-31. London, UK and Sterling, VA, USA: Earthscan.

Meidinger, E. (1985) On explaining the development of 'emissions trading' in US air pollution regulation. Law and Policy 7(4): 44779.

Millennium Ecosystem Assessment (2005) Millennium Ecosystem Assessment Synthesis Report. Millennium Ecosystem Assessment [www document]. URL http://www.rivm.nl/ bibliotheek/digitaaldepot/MAgeneralsynthesis.pdf

OECD (1999) Handbook of biodiversity valuation. A guide for policy makers. OECD Publishing [www document]. URL http://earthmind.net/rivers/docs/oecd-handbook-biodiversityvaluation.pdf

OECD (2013) Scaling-up finance mechanisms for biodiversity. OECD Publishing [www document]. URL http://www.oecdilibrary.org/environment/scaling-up-finance-mechanisms-forbiodiversity_9789264193833-en

Ostrom, E. (2007) A diagnostic approach for going beyond panaceas. Proceedings of the National Academy of Sciences USA 104: 1518115187.

Ostrom, E. (2011) Background on the institutional analysis and development framework. Policy Studies fournal 39: 7-27.

Paloniemi, R., Apostolopoulou, E., Primmer, E., GrodzinskaJurczak, M., Henle, K., Kettunen, M., Tzanopoulos, J., Potts, S. G., van den Hove, S., Marty, P., McConville, A. \& Similä, J. (2012) Biodiversity conservation across scales: lessons from a science-policy dialogue. Nature Conservation 2: 7-19.

Peck, J. \& Theodore, N. (2010) Mobilizing policy: models, methods, and mutations. Geoforum 41(2): 169-74.

Peters, B. G. \& Van Nispen, F. K. (1998) Public Policy Instruments: Evaluating the Tools of Public Administration. Cheltenham, UK and Northampton, MA, USA: Edward Elgar Publishing Ltd.

Rip, A. \& te Kulve, H. (2008) Constructive technology assessment and socio-technical scenarios. In: The Yearbook of Nanotechnology in Society, Volume I: Presenting Futures, ed. E. Fisher, C. Selin \& J. M. Wetmore, pp. 49-70. Amsterdam, The Netherlands: Springer.

Rip, A., Schot, J. W. \& Misa, T. J. (1995) Constructive technology assessment: a new paradigm for managing technology in society. In: Managing Technology in Society. The Approach of Constructive Technology Assessment, ed. A. Rip, T.J. Misa \& J. Schot, pp. 1-12. London, UK and New York, NY, USA: Pinter Publishers.

Robertson, M. M. (2004) The neoliberalization of ecosystem services: wetland mitigation banking and problems in environmental governance. Geoforum 35(3): 361-73.
Robertson, M. M. (2006) The nature that capital can see: science, state, and market in the commodification of ecosystem services. Environment and Planning D: Society and Space 24(3): 36787.

Robinson, D. K. R. (2009) Co-evolutionary scenarios: an application to prospecting futures of the responsible development of nanotechnology. Technological Forecasting and Social Change 76(9): 1222-39.

Sabatier, P. A. \& Jenkins-Smith, H. C. (1993) Policy Change and Learning: An Advocacy Coalition Approach. Boulder, CO, USA: Westview Press.

Salamon, L. M. (2002) The Tools of Government: A Guide to the New Governance: A Guide to Nem Governance. Oxford, UK: Oxford University Press.

Schneider, A. \& Sidney, M. (2009) What is next for policy design and social construction theory? Policy Studies fournal 37(1): 103-19.

Schot, J. \& Rip, A. (1997) The past and future of constructive technology assessment. Technological Forecasting and Social Change 54: 251-268.

Simons, A. (2013a) Report on constituency formation and dynamics in the innovation of emissions trading and biodiversity trading. Working Paper. Department of Sociology, Technische Universität Berlin, Berlin, Germany [www document]. URL http://www.innovation-in-governance.org/publications.html (pdf copies available on request from the authors).

Simons, A. (2013b) Report on design controversies in the innovation of emissions trading and biodiversity trading. Working Paper. Department of Sociology, Technische Universität Berlin, Berlin, Germany [www document]. URL http://www.innovation-in-governance.org/publications.html (pdf copies available on request from the authors).

Simons, A., Lis, A. \& Lippert, I. (2014) The political duality of scalemaking in environmental markets. Environmental Politics 23(4): 632-649.

Simons, A. \& Voß, J.-P. (2015) Politics by other means. The making of the emissions trading instrument as a 'pre-history' of carbon trading. In: The Politics of Carbon Markets, ed. B. Stephan \& R. Lane, pp. 51-68. New York, NY, USA: Routledge.

Soileau, D. M., Fruge, D. W. \& Brown, J. D. (1984) Mitigation banking: a mechanism for compensating unavoidable fish and wildlife habitat losses. The Environmental Lam Reporter 7(3): 11.

Stone, D. (2004) Transfer agents and global networks in the 'transnationalization' of policy. Fournal of European Public Policy 11(3): 545-66.

Sullivan, S. (2012) Banking nature? The spectacular financialization of environmental conservation. Antipode 45(1): 198-217.

TEEB (2008) The economics of ecosystems and biodiversity. An interim report [www document]. URL http://ec.europa.eu/ environment/nature/biodiversity/economics/pdf/teeb_ report.pdf

TEEB (2010) Mainstreaming the economics of nature: a synthesis of the approach, conclusions and recommendations of TEEB [www document]. URL http://www.teebweb.org/ TEEBSynthesis-Report/tabid/29410/Default.aspx

ten Kate, K., Bishop, J. \& Bayon, R. (2004) Biodiversity offsets: views, experience, and the business case. Report. IUCN, Gland, Switzerland and Cambridge, UK, and Insight Investment, London, UK [www document]. URL https://www.biodiv.org/doc/case-studies/inc/cs-inc-IUCNII-report-en.pdf 
The Energy \& Biodiversity Initiative (2003) Integrating biodiversity conservation into oil and gas development [www document]. URL http://www.theebi.org/pdfs/ebi_report.pdf

Tommel, I. \& Verdun, A. (2008) Innovative Governance in the European Union: The Politics of Multilevel Policymaking. Boulder, CO, USA: Lynne Rienner Publishers Inc.

UNCSD (2012) Rio+20 issues briefs [www document]. URL http: / / www.uncsd2012.org/index.php? $m e n u=138$

US FWS (2009) Conservation banking. Incentives for stewardship [www document]. URL http://www.fws.gov/ southwest/es/Documents/R2ES/conservation_banking.pdf

US FWS (2003) Guidance for the establishment, use, and operation of conservation banks, issued through a memorandum to regional directors, 2 May 2003, by the US Department of the Interior and the Fish and Wildlife Service, Washington, DC, USA. Federal Register 60(228): 58605-58614 [www document]. URL http://water.epa.gov/lawsregs/guidance/wetlands/ mitbankn.cfm

Van de Ven, A.H., Polley, D.E., Garud, R. \& Venkataraman, S. (1999) The Innovation Fourney. New York, NY, USA: Oxford University Press.
Voß, J.-P. (2007) Innovation processes in governance: the development of 'emissions trading' as a new policy instrument. Science and Public Policy 34(5): 329-343.

Voß, J.-P. \& Simons, A. (2014) Instrument constituencies and the supply-side of policy innovation. Environmental Politics 23(5): 735-754.

Wheeler, D. P. \& Strock, J. M. (1995) Official policy on conservation banks. The Resources Agency and California Environmental Protection Agency [www document]. URL http://www.forest-trends.org/publication_details.php? publicationID $=628$

Wilcove, D. S. \& Lee, J. (2004) Using economic and regulatory incentives to restore endangered species: lessons learned from three new programs. Conservation Biology 18(3): 639645.

Wolff, F., Schleyer, C. \& Arts, B. (2015) Discourses and politics of market-based instruments for ecosystem services. Environmental Policy and Governance (in press).

Yearley, S. (1994) Understanding science from the perspective of the sociology of scientific knowledge: an overview. Public Understanding of Science 3(3): 245-58. 